\title{
The Role of Foreign Trade in China's Economic Growth--An Empirical Study Based on EVA Model
}

\author{
Yichen Li \\ School of economics, Hefei University of Technology, Hefei Anhui, 230601, China
}

Keywords: Foreign Trade, Economic growth, Extreme Value Analysis Boundary.

\begin{abstract}
Based on the SITC, Chinese foreign trade products are divided three categories of products as resources and labor-intensive, capital-intensive and technology-intensive products, use Extreme Value Analysis Boundary (EBA) to conduct empirical study to identify the "robustness" factor for impacting China's economic growth. The results prove that the export trade, especially resources and labor-intensive and technology-intensive products has a robust, interference with Chinese economic growth. According to relevant policy recommendations put forward by China to promote sustained, rapid and healthy operation of Chinese economy.
\end{abstract}

\section{Introduction}

Since the 20th century, with the global trend of economic integration growing, the pace of development of China's foreign trade has also risen rapidly. It not only serves as a connection between China and the world's bond and bridge, but after the reform and opening up China's economic growth has made a great contribution. 2013, President Xi Jinping put forward "along the way" concept of development, China will open the door to expanded from coastal areas inland, to further promote the interaction and integration of our economy with the world economy. However, in recent years, China's economic downward pressure, many scholars have blamed China's foreign trade policy, calling for the development of domestic demand-led economic transformation. In this backdrop, this paper empirical research on the correlation between China's foreign trade and economic growth, in order to develop foreign trade development policy in line with China's national conditions, in order to better play a role in promoting foreign trade will have on our economy It is extremely important.

For the intrinsic relationship between economic growth and foreign trade, the theory has always been held by three different views: the promotion of trade theory, trade theory and hinder trade maid Dynasty. Similarly, empirical studies have different conclusions. Santos, Ribeiro and Carvalho (2013) ${ }^{[1]}$ EU Member States 1995-- Panel Data 2010 launched a study found that economic growth in the EU member states the power from the export of high value-added products and export more diversified countries, economic the higher the level of development, the positive effect of foreign trade on economic growth in the EU the more remarkable. Ning (2015) ${ }^{[2]}$ adopted across multiple distributed lag model to study the short- and long-term effects of three decades of foreign trade to economic growth, and the results show that foreign trade on China's economic growth in the long-term contribution coefficient 0.779-0.794 , and the impact will be revealed in two years. However, contrary to the results also appeared in other empirical studies. Dowrick and Golley (2004) ${ }^{[3]}$ The empirical results show that, after the 1980s, when more open global trade environment, the impact of foreign trade on the economy of poor countries is negative. The empirical results Huang Xinfei and Shu Yuan (2007) ${ }^{[4]}$ also noted that exists between trade openness and economic growth in China long-term equilibrium relationship and increase trade openness does not directly promote economic growth.

Thus, both theoretical perspectives and empirical research, academics are not in whether foreign trade promotes economic growth to reach a consensus on this issue. In this paper, the use of extreme value analysis Boundary (EBA), the relationship between China's foreign trade and economic growth between empirical research. 


\section{EBA Model}

\section{Basic Model.}

The basic model of EBA is as follows:

$$
\mathrm{Y}=\alpha+\beta_{\mathrm{i}} \mathrm{I}+\beta_{\mathrm{m}} \mathrm{M}+\beta_{\mathrm{z}} \mathrm{Z}+\mu
$$

In the above formula $\mathrm{Y}$ is the dependent variable; $\mathrm{I}$ is a set of core variables and $\mathrm{Y}$ variables directly related; $M$ is the target variable upcoming research in the text; $\mathrm{Z}$ is a group other than the $\mathrm{M}$ variable, other $\mathrm{Y}$ variables related to potential important explanatory variables; is a constant term; is a random error term.

\section{Model Test.}

First, I and $\mathrm{M}$ of variables that are basic regression models, to determine the variable $\mathrm{M}$ coefficients; EBA then use the model to find the maximum and minimum target variable factor $\mathrm{M}$, to determine the boundaries of the model's maximum, minimum boundary, wherein and the difference between the standard and, respectively.

Only results also meet the following three conditions:

(1) $\beta_{\mathrm{m}} \in[\beta, \bar{\beta}]$;

(2) $0 \notin[\underline{\beta}, \bar{\beta}]$;

(3) $\beta_{\mathrm{m}} 、 \beta_{\mathrm{m}-\max }$ and $\beta_{\mathrm{m}-\mathrm{min}}$ Statistical results are significant;

We can say is the relationship between the explanatory variables and the target variable is the "sound".

\section{Empirical Analysis}

\section{Variables Setting and Data Sources.}

a. Variable Y: The average Chinese per capita GDP growth rate (GDP).

b. Variable I: investment (INV) and the final consumption rate (CR).

c. Variable M: export growth (GEX), resources, and labor-intensive products accounted for the proportion of exports (ERMLIG), capital-intensive products accounted for the proportion of exports (ECIG), technology-intensive products accounted for the proportion of exports (ESIG), import growth (GIM) , resources, and labor-intensive products accounted for the proportion of imports (IRMLIG), capital-intensive products accounted for the proportion of imports (ICIG), technology-intensive products accounted for the proportion of imports (ISIG).

"Standard International Trade Classification" (SITC) the trade section is subdivided into 10 categories, 50 categories, 150 classes and 570 subclasses to reflect the degree of processing and production sector sources, the level of product developed by the United Nations . In this paper, based on SITC, further foreign trade products into resources and labor-intensive, capital-intensive and technology-intensive goods and products into three categories, the specific classification criteria are as follows:

\begin{tabular}{lll}
\hline Product Category & Definition & Combination \\
\hline $\begin{array}{l}\text { Resources and } \\
\text { Labor-intensive Products }\end{array}$ & $\begin{array}{l}\text { In factors of production, products that } \\
\text { resources and labor input ratio is higher than } \\
\text { the other proportion factors the product }\end{array}$ & $\begin{array}{l}\text { SITC 0 Food and live animals } \\
\text { SITC 2 non-food raw materials exclude } \\
\text { fuel } \\
\end{array}$ \\
& & SITC 3.2 coal, coke and briquettes \\
& & SITC 4 Animal and vegetable oils, fats \\
and waxes & SITC 6 main raw material manufactured \\
& & by classification (except SITC \\
& & 6.2,6.7,6.8) \\
& SITC 8 Miscellaneous manufactured \\
& articles (except SITC 8.7, SITC 8.8) \\
\hline Capital-intensive Products & $\begin{array}{l}\text { In factors of production, products that capital } \\
\text { input ratio is higher than the other proportion } \\
\text { factors the product }\end{array}$ & SITC 1 Beverages and tobacco \\
& SITC 3 Mineral fuels, lubricants and \\
& related materials (except SITC 3.2)
\end{tabular}


Technology-intensive Products
In factors of production, products that technology input ratio is higher than the other proportion factors the product
SITC 5.3 staining materials, tanning and pigment

SITC 5.5 balms and essential oils and spices; toiletries and clean supplies

SITC 5.6 Fertilizer

SITC 6.2 Rubber Products

SITC 6.7 Steel

SITC 6.8 non-ferrous metal

SITC 7 Machinery and transport equipment (except SITC 7.1,7.3,7.9)

SITC 5 Chemicals and related products (except SITC 5.3,5.5,5.6)

SITC 7.1 Power Machinery \& Equipment SITC 7.3 Metal Processing Machinery SITC 7.9 other vans

SITC 8.7 Professional, scientific and controlling instruments and apparatus SITC 8.8 photographic apparatus, equipment and materials and optical products; watches and clocks

d. Variable Z: expenditure growth rate (NE), household savings rate (SR), Research and experimental development technology investment growth rate (RDI), total fixed asset investment to GDP ratio (TI) and the growth rate of high school graduation rates (HS).

This paper adopts data of China in 1996--2014 for the study sample, data from the China Statistical Yearbook, Chinese Foreign Economic Trade Statistics Yearbook and the United Nations Commodity Trade Database.

\section{Basic Model Test.}

In this section, only variables I and $\mathrm{M}$ used for linear regression model, whether the result of the determination coefficient $\mathrm{M}$ statistical significance. This paper use of export and import data on per capita GDP tested, results are summarized as follows:

\begin{tabular}{|c|c|c|c|}
\hline Object Variable & $\beta_{\mathrm{m}}$ & $\begin{array}{l}\mathrm{P} \\
\text { Value } \\
\end{array}$ & Pass/Fail \\
\hline Export Growth（GEX） & 0.0932 & 0.0974 & Pass \\
\hline $\begin{array}{l}\text { Proportion of Resources and } \\
\text { labor-intensive products accounted for the } \\
\text { exports } \\
\text { (ERMLIG) }\end{array}$ & 0.0182 & 0.0002 & Pass \\
\hline $\begin{array}{l}\text { Proportion of capital-intensive products } \\
\text { accounted for the exports } \\
\text { (ECIG) }\end{array}$ & -3.1653 & 0.5811 & Fail \\
\hline $\begin{array}{l}\text { Proportion of technology-intensive } \\
\text { products accounted for the exports } \\
\text { (ESIG) }\end{array}$ & 0.0244 & 0.0009 & Pass \\
\hline Import Growth（GIM） & 0.0032 & 0.0001 & Pass \\
\hline $\begin{array}{l}\text { Proportion of Resources and } \\
\text { labor-intensive products accounted for the } \\
\text { imports } \\
\text { (IRMLIG) }\end{array}$ & -0.0124 & 0.4065 & Fail \\
\hline $\begin{array}{l}\text { Proportion of capital-intensive products } \\
\text { accounted for the imports } \\
\text { (ICIG) }\end{array}$ & -0.0011 & 0.0001 & Pass \\
\hline $\begin{array}{l}\text { Proportion of technology-intensive } \\
\text { products accounted for the imports } \\
\text { (ISIG) }\end{array}$ & 0.0645 & 0.0016 & Pass \\
\hline
\end{tabular}

Note: The significance level is $10 \%$. 
As can be seen from the results, only the export growth rate (GEX), resources, and labor-intensive products accounted for the proportion of exports (ERMLIG), technology-intensive products accounted for the proportion of exports (ESIG), import growth (GIM), capital-intensive products accounted for imports ratio (ICIG), technology-intensive products accounted for the proportion of imports (ISIG) six variables regression pass the test, we test the "robustness" in the next step.

\section{"Robustness" Test.}

In this part, the paper added variable $\mathrm{Z}$ and all linear combinations, conduct the "robustness" test for six variables which pass the first step of the test. Test results are as follows:

\begin{tabular}{|c|c|c|c|c|c|}
\hline Object Variable & $\begin{array}{l}\text { Boundary } \\
\text { Extremum }\end{array}$ & Coefficient & P Value & $\begin{array}{l}\text { Robust/unr } \\
\text { obust }\end{array}$ & Reason \\
\hline \multirow{2}{*}{$\begin{array}{l}\text { Export Growth } \\
\text { (GEX) }\end{array}$} & Maximum & 0.2637 & 0.0000 & \multirow[t]{2}{*}{ Robust } & \\
\hline & Minimum & 0.0317 & 0.0000 & & \\
\hline \multirow{2}{*}{$\begin{array}{l}\text { Proportion of } \\
\text { Resources and } \\
\text { labor-intensive } \\
\text { products accounted } \\
\text { for the exports } \\
\text { (ERMLIG) }\end{array}$} & Maximum & 0.0463 & 0.0261 & \multirow{2}{*}{ Robust } & \\
\hline & Minimum & 0.001 & 0.0000 & & \\
\hline \multirow{2}{*}{$\begin{array}{l}\text { Proportion of } \\
\text { technology-intensive } \\
\text { products accounted } \\
\text { for the exports } \\
\text { (ESIG) }\end{array}$} & Maximum & 0.0693 & 0.0000 & \multirow[t]{2}{*}{ Robust } & \\
\hline & Minimum & 0.0137 & 0.0070 & & \\
\hline \multirow{2}{*}{$\begin{array}{l}\text { Import Growth } \\
\text { (GIM) }\end{array}$} & Maximum & 0.037 & 0.3256 & \multirow{2}{*}{ Unrobust } & $\begin{array}{l}\text { The symbol is } \\
\text { different for }\end{array}$ \\
\hline & Minimum & -0.2897 & 0.0746 & & $\begin{array}{l}\text { Maximum and } \\
\text { Minimum }\end{array}$ \\
\hline \multirow{2}{*}{$\begin{array}{l}\text { Proportion of } \\
\text { capital-intensive } \\
\text { products accounted } \\
\text { for the imports } \\
\text { ( ICIG) }\end{array}$} & Maximum & -0.2589 & 0.9652 & \multirow[t]{2}{*}{ Unrobust } & $\begin{array}{l}\text { Coefficient } \beta_{\mathrm{m}} \text { is not } \\
\text { in the range } \\
\text { constituted by the }\end{array}$ \\
\hline & Minimum & -6.5871 & 0.7091 & & $\begin{array}{l}\text { maximum value and } \\
\text { the minimum value }\end{array}$ \\
\hline \multirow{2}{*}{$\begin{array}{l}\text { Proportion of } \\
\text { technology-intensive } \\
\text { products accounted } \\
\text { for the imports } \\
\text { (ISIG) }\end{array}$} & Maximum & 0.01679 & 0.4846 & \multirow{2}{*}{ Unrobust } & \multirow{2}{*}{$\begin{array}{l}\text { Coefficient } \beta \mathrm{m} \text { is not } \\
\text { in the range } \\
\text { constituted by the } \\
\text { maximum value and } \\
\text { the minimum value }\end{array}$} \\
\hline & Minimum & 0.0004 & 0.2565 & & \\
\hline
\end{tabular}

By the above table, it can be seen that only export growth (GEX), resources, and labor-intensive products accounted for the proportion of exports (ERMLIG), technology-intensive products accounted for the proportion of exports (ESIG) three variables tested model, suggesting that export growth export resource exports and labor-intensive products and technology-intensive products to China's economic growth has a positive, anti-interference "robustness" relationship.

\section{Conclusion and Suggestions}

The empirical results can be seen, export growth is still enormous engine of China's economic growth, but resource exports and labor-intensive products, the proportion of technology-intensive products accounted for the higher role in boosting China's economic growth will be. According to this paper, the following three policy recommendations:

Increase Foreign Trade System Reform Effort.

Reduce excessive government intervention in the market, greatly enhance the degree of economic liberalization, so as to form international economies benign interaction; adhere to open development 
strategy and achieve win-win cooperation through trade; formulate and improve relevant laws and regulations based on the actual development, the introduction of information technology, modern, transparent management system, improve the coordination of follow-up services, and guide foreign trade and the economy healthy and rapid development.

\section{Optimize the Product Structure of Foreign Trade.}

Full implementation of science and technology trade strategy. On the one hand to continue to play our resources and abundant labor pool, low-cost comparative advantages, and actively introduce foreign advanced technology, process and equipment, the existing labor-intensive industrial upgrading; the other hand, focus on supporting and development of capital-intensive modern high-tech industries and technology-intensive, attention and cultivate new economic growth point. Through the optimization and upgrading of industrial structure and technological progress continue to improve the precision and quality of China's foreign trade products, increase high value-added and high-tech products in the proportion of the export trade, and enhance the international competitiveness of China's exports, to promote China's foreign trade pattern Evolution of a higher level.

\section{Cultivating Highly Competitive Edge Enterprises.}

Further opening up import and export business, to reduce the quota system, licensing system to bring negative impact, positive for qualified enterprises to declare relevant information and encourage qualified companies to choose a reliable proxy enterprises to enter the field of foreign trade; abandon the overall protection old ideas, promote foreign trade enterprises independent, self-financing, self-management, self-correction, and enhance their own advantages, enhance the ability to resist risks; encourage enterprises to absorb a wide range of high-level talents, guide enterprises in research and development, strengthen the institutions of higher learning and scientific research units technical support for enterprise innovation, thereby enhancing the ability of independent innovation of enterprises.

\section{References}

[1] Santos P G, Ribeiro A P, Carvalho V M. Export-led growth in Europe: Where and what to export, Fep Working Papers, 2013.

[2] Chen Ning. FDI, Empirical Study for International Trade and Economic Growth, Statistics and Decision, 2015,08: 135-138.

[3] Dowrick S, Golley J. Trade openness and growth: who benefits? Oxford review of economic policy, 2004, 20(1): 38-56.

[4] 2007,12:11-17. Huang Xinfei, Shu Yuan. Research on Trade Openness and Industrial Specialization and Chinese Economic Growth, International Trade Issues, 2007,12: 11-17. 